\begin{tabular}{|c|c|c|}
\hline $\begin{array}{l}\text { Asian Journal of Pharmaceutical Research } \\
\text { and Development } \\
\text { (An International Peer-Reviewed Journal of Pharmaceutical Research and Development) }\end{array}$ & & No \\
\hline $\begin{array}{l}\text { O 2013-18, publisher and licensee AJPRD, This is an Open Access article which permi } \\
\text { non-commercial use, provided the original work is properly cited }\end{array}$ & D & \\
\hline
\end{tabular}

\title{
ETHANOL EXTRACT AND ACTIVE FRACTION EFFECT OF Moringa Oleifera. Lam IN INHIBITING COX-2 ACTIVITY ON MCF-7 CELL
}

\section{Azizah*1, Masfria², AZH. Poppy3}

${ }^{1}$ Graduate Student, Faculty of Pharmacy, Universitas Sumatera Utara, Medan, 20155 Indonesia.

${ }^{2}$ Department of Pharmaceutical Chemistry, Faculty of Pharmacy, Universitas Sumatera Utara, Medan, 20155, Indonesia.

3Department of Pharmacology, Faculty of Pharmacy, Universitas Sumatera Utara, Medan, 20155 Indonesia.

\begin{abstract}
The expression of COX-2 is involved in carcinogenesis through the proliferative process, angiogenesis and inhibition of apoptosis. Moringa oleifera has been shown to function as an anti-oxidant, anti-inflammatory, anti-microbial and anticancer. Moringa leaf extraction was done by percolation method, and continued to liquid-liquid extraction to obtain nonpolar, semipolar, and polar fractions using $n$-hexane and ethylacetate solvent. The aim of this study was to determine the effect of ethanol extract and the fraction of n-Hexane of Moringa oleifera leaf in decreased MCF-7 breast cancer cell and COX-2 expression. This study used true experimentation in vitro design using MCF-7 cells. MTT Assay was performed using a therapeutic dose 6,125-1000 $\mu \mathrm{g} / \mathrm{ml}$ to determine IC50 in MCF-7 cells. IC50 of ethanol extract was obtained $94.44 \mu \mathrm{g} / \mathrm{ml}$ and $97.60 \mu \mathrm{g} / \mathrm{ml}$ for n-Hexane fraction. Selectivity index of both samples was $3.95 \mu \mathrm{g} / \mathrm{ml}$ and $2.87 \mu \mathrm{g} / \mathrm{ml}$. The expression of COX-2 was tested qualitatively with immunocytochemical methods and showed that ethanol extract and n-hexane fraction of Moringa oleifera leaf were able to suppress COX-2 enzyme expression on MCF-7 cells depending on concentration.
\end{abstract}

Keywords: Moringa leaf, cancer cells MCF-7, Apoptosis and COX-2

Article Info: Received 29 July, 2018;

Review Completed 18 Aug 2018;

Accepted 21 Aug 2018;

Cite this article as:

Azizah D., Ethanol Extract and Active Fraction Effect of Moringa Oleifera. Lam In Inhibiting Cox-2 Activity On Mcf-7 Cell,,Asian Journal of Pharmaceutical research and Development.2018;6 (4): 0105

DOI: http://dx.doi.org/10.22270/ajprd.v6.i4. 399

*Address for Correspondence

D. Azizah, Graduate Student, Faculty of Pharmacy, Universitas Sumatera Utara, Medan, 20155 Indonesia.

\section{INTRODUCTION}

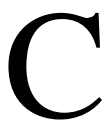
ancer has a major impact on society in across the world, both men and women. 5 types of cancer which cause of death in women are breast cancer, cervix, colon, lung, and stomach ${ }^{1}$. Based on National Cancer Institute data, side effects that may occur due to anthracycline-based chethanol extracttherapy (doxorubicin) are nausea, vomiting, diarrhea, stomatitis, alopecia, susceptible to infection, thrombocytopenia, neuropathy, and myalgia ${ }^{2}$.Several research proved that the potential of Moringa leaf as an anti-cancer agent, the content of benzyl isothiocyanate (BITC) in Moringa leaf in vitro is able to induce apoptosis against ovarian cancer cells ${ }^{3}$.The Moringaleaf extract can decrease the activity of cancer cells HepG2 and Caco- $2{ }^{4}$. The flavonoid content found in Moringa leaf has the potential to be an anti-cancer agent by inhibiting proliferation and inducing apoptosis of cancer cells ${ }^{5}$. Effect Moringa oleifera leaf in inhibiting the growth of cancer cells MCF-7 has been proven, but effect of the active fraction of ethanol extract of Moringa leaf on apoptosis and expression of COX-2 on MCF-7 cells have never been done. Because of that, it is necessary to conduct research on the cytotoxic effects of ethanol extracts and its fractions on MCF-7 cells and its effects on apoptosis and COX-2 expression. 


\section{MATERIAL AND METHODS}

\section{Plant Material}

The Moringa leaf sample was collected from East Dumai, Riau, Indonesia.

\section{Extraction of Moringa leaf}

An amount of $400 \mathrm{~g}$ dried material plant samples were crushed in a blender, then macerated in ethanol $96 \%$ for 3 hours thereafter moved to perlocator tube. Percolation was stopped if the last $500 \mathrm{mg}$ of solvent were evaporated, leaving no residuals. The solvent was evaporated at low pressure with a temperature of not more than $40^{\circ} \mathrm{C}$ using a Rotary evaporator. It is then taken $20 \mathrm{~g}$ for liquid-liquid extraction to obtain a nonpolar, semipolar, and polar fraction using n-hexane and ethylacetate solvents

\section{Phytochemical screening Moringa leaf}

Phytochemical screening carried out on moringa leaf includes examining the chemical secondary metabolites of alkaloids, flavonoids, glycosides, tannins, saponins, triterpenoids, and steroids

\section{Exposure of Moringa Leaf Extract on Cell Culture}

The ethanol extract and the fraction of moringa leaf were diluted based on selected concentration to MCF-7 cell medium. The extract of moringa leaf extract was added to the plate and allowed to stand for 24 hours. Rewashed the extract of moringa leaf extract with the cell medium.

\section{Exposure of Moringa Leaf Extract on Cell Culture}

The ethanol extract and the fraction of the moringa leaf were diluted according to the desired concentration in the MCF-7 cell medium. The moringa leaf extract was added to the plate and allowed to stand for 24 hours. Rewashed the moringa leaf extract with the cell medium.

\section{Cytotoxic Test with Assay-MTT Method}

\section{Cytotoxic Assay-MTT Method}

MCF-7 cells $\left(5 \times 10^{3}\right.$ cells/well) were transferred in 96well plate and incubated for 24 hours (70-80\% confluent). Cells were treated by ethanol extract and fraction of moringa leaf, then incubated for 24 hours. At the end of the treatment incubation, MTT [3-(4,5 - dimethylthiazol-2-yl) -2,5-diphenyl tetrazolium bromide] $0.5 \mathrm{mg} / \mathrm{ml}$ was added to each well followed by 4 hours incubation in $37^{\circ} \mathrm{C}$ chamber. Viable cells react with MTT to form purple formazan crystals. After 4 hours, stopper sodium dodesil sulphate (SDS) $10 \%$ in $0,1 \mathrm{~N} \mathrm{HCl}$ solution was added to dissolve the formazan crystals. Following overnight incubation (with protection from light exposure), the cells were shaken for 10 minutes before being read by an ELISA reader at $\lambda$ 595 NM.

\section{Apoptosis Test}

\section{Apoptosis Assay (Double Staining Method)}

Cells $\left(5 \times 10^{4}\right.$ cells/well $)$ were seeded on coverslips (Nunc) in a 24-well plate (Iwaki) and incubated for 24 hours (50-60\% confluent). Cells were then treated by ethanol extract and fraction of moringa leaf, followed by incubation for 15 hours. At the end of the incubation, coverslips containing cells were moved to object glass and a mixture solution of etidium bromide- acridine orange (Sigma, Sigma-Aldrich Corp, St. Louis, MO, USA) were added to the cells to form fluorescent cells. The fluorescent cells were examined by fluorescence microscope (Zeiss MC80) immediately. Green flourecent cells showed viable cells, while red fluorescent cells showed dead cells.

\section{Immunocytochemical Test}

The cell suspension at each different well (density of cells $5 \times 10^{5}$ cells/well) was added $1000 \mu \mathrm{L}$ samples in the DMEM (Dulbecco`s Modified Eagle Media) culture medium until the series reaches the end in the wells of $1 / 2 \mathrm{IC}_{50}$ and $1 / 10 \mathrm{IC}_{50}$. In the control group added 1000 $\mu \mathrm{L}$ culture medium. The plates were incubated in a $5 \%$ $\mathrm{CO}_{2}$ incubator for 24 hours at $37^{\circ} \mathrm{C}$. The incubated cells were then harvested and crushed on the object glass to be immunocytochemically tested using a COX-2 monoclonal primer (IgG) antibody, and visualized by color reaction. The expression of COX-2 is observed using a light microscope. The cells expressing the COX2 protein will give a brown or dark color, and the cells which did not expressing the COX-2 showed color of violet or blue. The number of cells is calculated on a certain area, both brown / dark and colored blue, then analyzed.

\section{Data Analysis}

The obtained absorbance of each well converted to percentage of viable cells :

$$
\% \text { viable cells }=\frac{\text { Treated cells abs-Medium control abs }}{\text { X 100\% }}
$$

Cells control abs-Medium control abs

Differences in cell viability at each incubation time due to sample treatment with various series of concentrations in cell control were analyzed using SPSS 16.0 with ANOVA (Analysis of variance) and 95\% Confidence Interval.

\section{RESULTS}

\section{Extraction and Phytochemical Screening}

Moringa leaf extraction results obtained extract of 74.44 g. Result of liquid liquid extraction obtained n-hexane fraction as much as 19,16 g; ethylacetate fraction 17,37 $\mathrm{g}$; and water fraction as much as $15,83 \mathrm{~g}$. The results of phytochemical tests obtained include ethanol extract and fraction of moringa leaf containing of flavonoids, triterpenoids / steroids and glycosides (negative water fractions). The alkaloids are positive for ethanol extracts and water fractions.

\section{Dose of IC $_{50}$ with MTT Assay}

Cytotoxicity test using MTT assay methods. The concentration series of ethanol extract and fraction of cytotoxic test against MCF-7 cells was 1000; 500; 250; $125 ; 62.50 ; 31,25 ;$ and $15,625 \mu \mathrm{g} \mathrm{/} \mathrm{ml}$. The concentration of doxorubicin was $24 ; 12 ; 6 ; 3 ; 1,5$; 0,75 and $0.375 \mu \mathrm{g} / \mathrm{ml}$. The graph of $\mathrm{IC}_{50}$ value comparison between the test materials can be seen in Figure 1. 


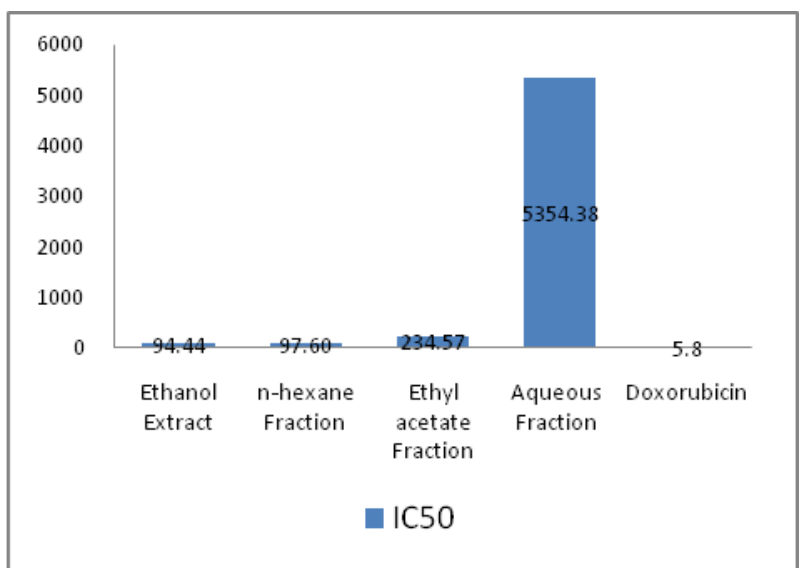

Figure 1. $\mathrm{IC}_{50}$ values of ethanol extract and Moringa leaf fraction of MCF-7 cells

To determine the safety of use of Moringa leaves against normal cells, cytotoxic test was also performed on vero cells which are normal renal cells of African green primates. The graph of $\mathrm{IC}_{50}$ value comparison between the test materials can be seen in Figure 2.The value of $\mathrm{IC}_{50}$ of ethanol extract and fraction to vero cell and to MCF-7 cells were used to calculate the selectivity index. The results of selectivity index calculation can be seen in Table 1 below.

Table 1. Selectivity index of samples on MCF-7 cells

\begin{tabular}{|c|l|c|}
\hline S.no. & $\begin{array}{l}\text { Extract/fraction of Moringa } \\
\text { leaf }\end{array}$ & $\begin{array}{c}\text { Selecivity } \\
\text { index }\end{array}$ \\
\hline 1. & Ethanol extract & 3.95 \\
\hline 2. & $n$-hexane fraction & 2.87 \\
\hline 3. & Ethyl acetate fraction & 2.73 \\
\hline 4. & Water fraction (residual) & 0.34 \\
\hline
\end{tabular}

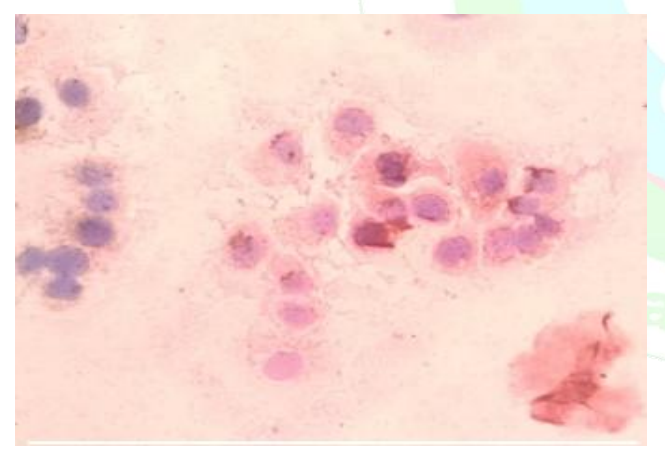

(a)

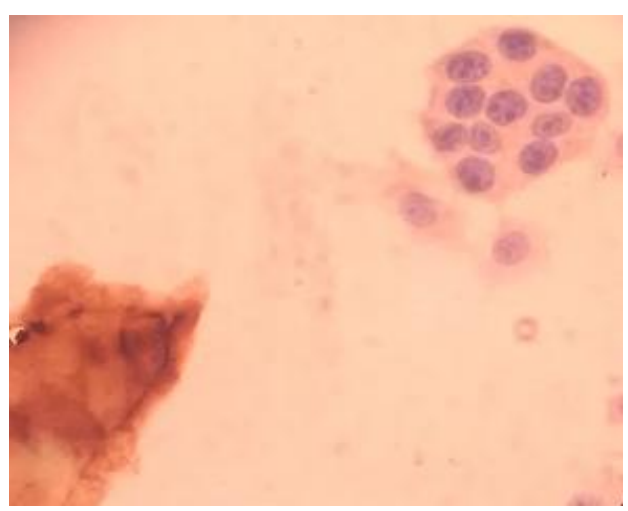

(b)

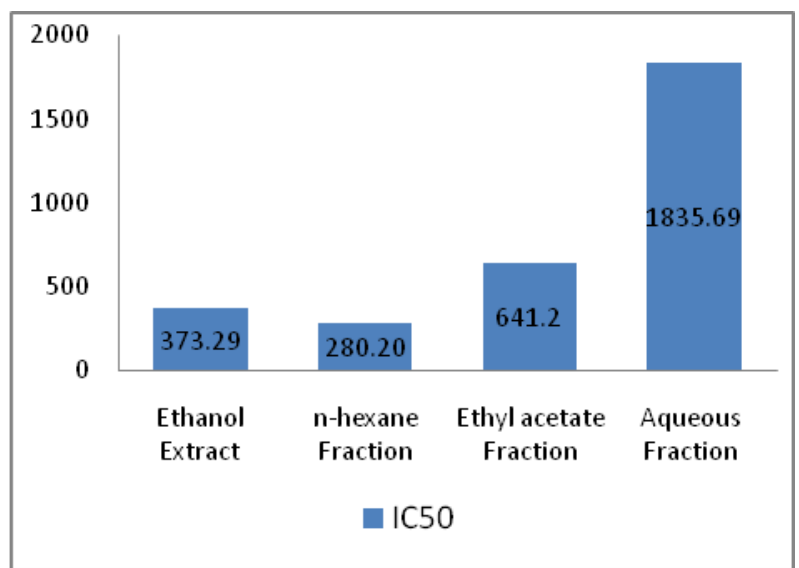

Figure 2. $\mathrm{IC}_{50}$ values of ethanol extract and leaves fraction of Moringa on vero cell

The apoptotic test was performed on MCF-7 cells with ethanol extract and n-hexane fraction moringa leaf as the test material because the two materials were the best tested materials with $\mathrm{IC}_{50}$ among other test materials. The result of apoptotic test showed that ethanol extract and n-hexane fraction of Moringa leaf against MCF-7 cells caused late necrotic cells. The final necrotic cell present also occurs by administration of doxorubicin.

\section{Immunocytochemistry}

Based on observations using a light microscope with $1000 x$ magnification, it can be seen the increase and decrease of COX-2 expression on MCF-7 cells in the control of cells without treatment and with dosage $1 / 2$ $\mathrm{IC}_{50}$ and $1 / 10 \mathrm{IC}_{50}$, results showed in Figure 3.

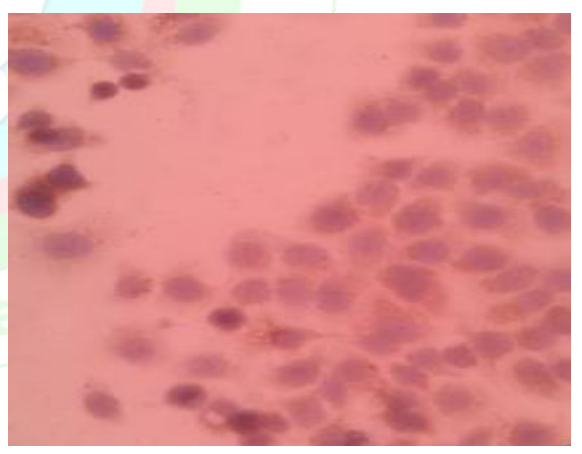

(b)

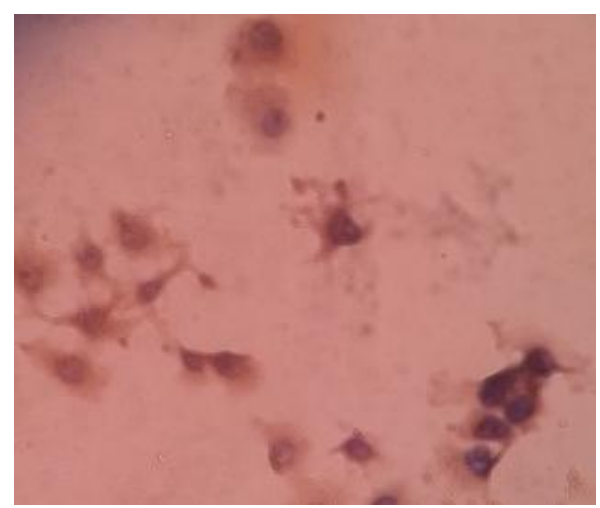

(d) 


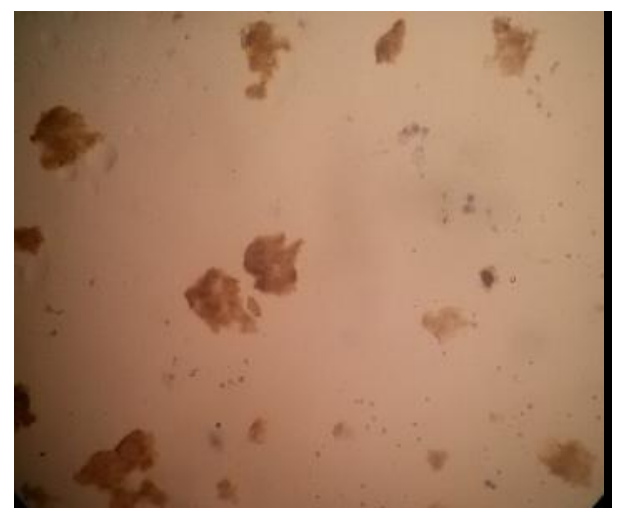

(e)

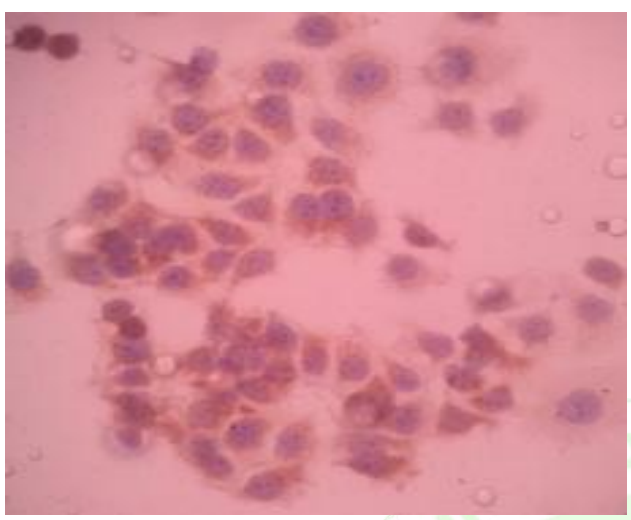

(g)

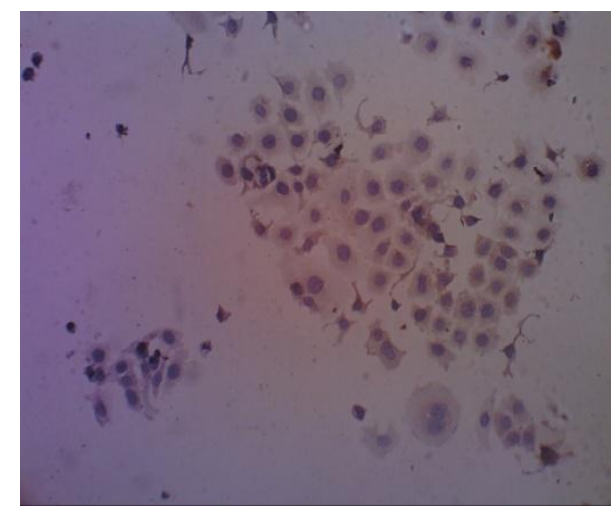

(f)

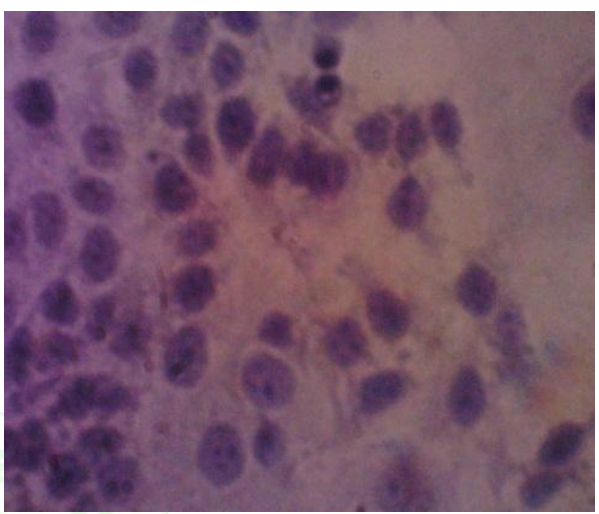

(h)

Figure 3. Microscopic observation of MCF-7 cell cultures using immunocytochemical methods showing active COX-2 showed dark brown color and COX-2 inactive showed brown violet color. Description: (a) treatment group at dose of $1 / 2$ IC50 ethanol extract, (b)Treatment group at dose of 1/10 IC50 ethanol extract, (c) treatment group at dose of $1 / 2 \mathrm{IC}_{50} \mathrm{n}$-hexane fraction, (d) treatment group at dose of $1 / 10$ IC50 n-hexane fraction (e) treatment group at dose of $1 / 2$ IC50 Doxorubicin, (f) treatment group at dose of $1 / 10$ IC50 Doxorubicin (g) control group with antibody, (h) control group without antibody.

\section{DISCUSSION}

MTT assay was performed to determine IC50 (Inhibition Concentration 50\%). Based on previous research, IC50 of Moringa leaf against pancreatic cancer obtained $1100 \mu \mathrm{g} / \mathrm{ml}^{6}$. In colon cancer cell type HCT15, SW48, and SW480 were respectively 264,83; 102,40 ; and $197.20 \mu \mathrm{g} / \mathrm{ml}^{7-8}$. Result of this study showed that dose of IC50 ethanol extract obtained 94.44 $\mu \mathrm{g} / \mathrm{ml}$ and $\mathrm{n}$-hexane fraction obtained $97.60 \mu \mathrm{g} / \mathrm{ml}$ to MCF-7 breast cancer cells.

There is a difference in dose of IC50 compare to previous study, it can be due to the difference type of cancer cells and the origin area of the moringa leaf that will affect the mechanism of action moringa leaf to MCF-7 cancer cells. $\mathrm{IC}_{50}$ ethanol extract and n-hexane fraction values obtained are included in the category of active compounds as anticancer because an extract is considered active if it has $\mathrm{IC}_{50} \leq 100 \mu \mathrm{g} / \mathrm{ml}^{9}$. Moringa leaf contains a unique chemical substance, namely isothiocyanate, glycocyanate, carbamate, thiocarbamate glycoside, phenolic, niazimicin, and flavonoids which in previous studies show biological activity such as antiinflammatory, antioxidant and anti-tumor 5,10 . Isotiocyanate in Moringa oleifera (L) leaf is particularly useful as a chethanol extractpreventive agent in cancer cells. It is in the nature in the form of benzyl isothiocyanate (BITC), phenytoil isothiocyanate (PEITC), and phenyl isothiocyanate (PITC) ${ }^{11}$.
The cytotoxicity test of extract and fraction of Moringa leaf was done on vero cell which is normal renal cell of African green ape to know the safety of Moringa leaf against normal cell. The value of IC50 extract and Moringa leaf fraction to vero cell and IC50 extract and Moringa leaf fraction of MCF-7 cells were used to calculate the selectivity index. The results of ethanol extract selectivity index calculations are more selective than n-hexane fraction. The extract is said to be selectively high if the value of SI $>3^{12}$.

Apoptosis observation was done by flowcytometry method. This method is a method to calculate live cells, necrotic cells and apoptosis quickly. In this test used a protein Annexin $\mathrm{V}$ that can bind specifically to phosphatidilserin contained in the cell plasma membrane during apoptosis process. DNA in damaged cells, both necrosis and apoptosis will be colored by propidium iodide (PI) which produces orange to red fluorescence. As it passes through the laser beam, the cell will excite and dissipate its light to produce fluorescence light ${ }^{13}$. The apoptosis test of ethanol extract and n-hexane fraction showed cell activity to undergo late necrosis.

In the immunocytochemical staining there were five treatment groups, ie 1/2 IC50, 1/10 IC50, control group (medium with primary antibody treatment), and blank (medium without primary antibody treatment) and doxorubicin. The results of COX-2 expression in the 
treatment group were then compared with the expression in the control group so it can be seen the effect of ethanol extract of Moringa leaves on COX-2 expression. Immunocytochemical painting results were observed using a light microscope. Positive COX-2 expression when cell cytoplasm is brown, and negative when cytoplasm is blue / dark (Fig. 3).

In the treatment group it was seen that COX-2 expression decreased with increasing levels of ethanol extract and n-hexane fraction. Decreasing the concentration of the test extract provides an increase in COX-2 expression which is inversely proportional to suppression of COX-2 expression. The flavonoid content of ethanol extract and n-hexane fraction is thought to be a decrease in COX-2 expression. The biological effects of flavonoids appear to be due to interactions with protein tyrosine kinases and cyclooxygenase enzymes. BITC reportedly suppresses COX-2 expression through inhibition of MAPKs and NF-KB signaling pathways ${ }^{14}$. The resulting activity of

\section{REFERENCES}

1. Yaacob NS, Hamzah N, Kamal NN, Abidin SA, Lai CS, Navaratnam V, Norazmi MN. Anticancer activity of a sub-fraction of dichloromethane extract of Strobilanthes crispus on human breast and prostate cancer cells in vitro. BMC complementary and alternative medicine. 2010 Dec;10(1):42.

2. Partridge AH, Burstein HJ, Winer EP. Side effects of chemotherapy and combined chemohormonal therapy in women with early-stage breast cancer. JNCI Monographs. 2001 Dec 1;2001(30):135-42.

3. Bose CK. Possible role of Moringa oleifera Lam. root in epithelial ovarian cancer. Medscape General Medicine. 2007;9(1):26.

4. Charoensin S. Antioxidant and anticancer activities of Moringa oleifera leaves. Journal of Medicinal Plants Research. 2014 Feb 17;8(7):318-25.

5. Sreelatha $S$, Padma PR. Antioxidant activity and total phenolic content of Moringa oleifera leaves in two stages of maturity. Plant foods for human nutrition. 2009 Dec 1;64(4):303.

6. Berkovich L, Earon G, Ron I, Rimmon A, Vexler A, Lev-Ari S. Moringa Oleifera aqueous leaf extract down-regulates nuclear factor-kappaB and increases cytotoxic effect of chemotherapy in pancreatic cancer cells. BMC complementary and alternative medicine. 2013 Dec;13(1):212.

7. Paliwal $R$, Sharma V, Pracheta J. A review on horse radish tree (Moringa oleifera): A multipurpose tree with high economic and commercial importance. Asian journal of Biotechnology. 2011;3(4):317-28.

8. Osborne CK, Hobbs K, Trent JM. Biological differences among MCF-7 human breast cancer cell lines from different laboratories. Breast cancer research and treatment. 1987 Jun 1;9(2):111-21.

9. Kamuhabwa A, Nshimo C, de Witte P. Cytotoxicity of some medicinal plant extracts used in Tanzanian traditional medicine. Journal of ethnopharmacology. 2000 May 1;70(2):143-9.

10. Cheenpracha S, Park EJ, Yoshida WY, Barit C, Wall
COX is prostaglandin, which is the result of arachidonic acid metabolism. Prostaglandins play a great role in human body systems, but when overexpressed, are reported to be involved in tumorigenesis 15 . Prostaglandins of COX-2 activity reportedly play a role in VEGF upregulation (vascular endothelial growth factor) and induce angiogenesis in tumors ${ }^{16}$. VEGF alone can increase the protein and activity of $\mathrm{COX}-2$ in Human Umbilical Vein Endothelial Cells (HUVEC) ${ }^{17}$.

\section{CONCLUSION}

From the research using ethanol extract and n-hexane fraction can be drawn the conclusion that ethanol extract and n-hexane fraction have active cytotoxic ability as anticancer compounds since they have $\mathrm{IC}_{50}$ value of 94.44 and $97.60 \mu \mathrm{g} / \mathrm{mL}$. Ethanol extract and n-hexane fraction cause cells to experience late necrosis in apoptosis testing using the flowsitomteri method.Ethanol extract and n-hexane fraction capable of suppressing the effect of cyclooxygenase- 2 enzyme expression.

M, Pezzuto JM, Chang LC. Potential antiinflammatory phenolic glycosides from the medicinal plant Moringa oleifera fruits. Bioorganic \& medicinal chemistry. 2010 Sep 1;18(17):6598-602.

11. Tamayo C, Richardson MA, Diamond S, Skoda I. The chemistry and biological activity of herbs used in Flor-Essence ${ }^{\mathrm{TM}}$ herbal tonic and Essiac. Phytotherapy Research: An International Journal Devoted to Pharmacological and Toxicological Evaluation of Natural Product Derivatives. 2000 Feb;14(1):1-4.

12. Machana S, Weerapreeyakul N, Barusrux S, Nonpunya A, Sripanidkulchai B, Thitimetharoch $T$. Cytotoxic and apoptotic effects of six herbal plants against the human hepatocarcinoma (HepG2) cell line. Chinese medicine. 2011 Dec;6(1):39.

13. Brussaard CP, Marie D, Bratbak G. Flow cytometric detection of viruses. Journal of virological methods. 2000 Mar 1;85(1-2):175-82.

14. Srivastava SK, Singh SV. Cell cycle arrest, apoptosis induction and inhibition of nuclear factor kappa $B$ activation in anti-proliferative activity of benzyl isothiocyanate against human pancreatic cancer cells. Carcinogenesis. 2004 Sep 1;25(9):1701-9.

15.Zecha $G$, Lin DW, Montgomery RB. The increasing role of CAM in prostate cancer: diet, antioxidants, COX-2 inhibitors, and certain herbs are among the numerous CAM interventions available for prostate cancer. Some show promise, but additional research is needed. JAAPA-Journal of the American Academy of Physicians Assistants. 2004 Mar 1;17(3):37-43.

16. Akarasereenont $P$, Techatraisak $K$, Thaworn A, Chotewuttakorn $S$. The expression of COX-2 in VEGF-treated endothelial cells is mediated through protein tyrosine kinase. Mediators of inflammation. 2002;11(1):17-22

17. Akiyama T, Ishida J, Nakagawa S, Ogawara $H$, Watanabe SI, Itoh N, Shibuya M, Fukami Y. Genistein, a specific inhibitor of tyrosine-specific protein kinases. Journal of Biological Chemistry. 1987 Apr 25;262(12):5592-5. 